\title{
Pengembangan Metode Penstrukturan Masalah Berbasis Cognitive Map dan Strategic Choice Approach dan Penerapannya pada Masalah Manajemen Rantai Pasok
}

\author{
Iwan Mu'min Basarah ${ }^{1 *}$, Sani Susanto
}

\begin{abstract}
The problem structuring methods used to deal with complex and ill-structured problems. One of the method of structuring ill-structured problem is the Strategic Choice Approach (SCA), while one of the problems of complex and ill-structured problems is a supply chain management problems. This research proposes the use of a cognitive map and SCA on the problems structuring method of supply chain management at Perseroan Terbatas X a leading manufacturing company in Indonesia. Three main results of this study are structuring problems, choosing of the top priority problems, and choosing of troubleshooting options among other identified options.
\end{abstract}

Keywords: Ill-structured problems; strategic choice approach; supply chain management

\section{Pendahuluan}

Tiga rangkaian kegiatan - merumuskan apa yang diketahui, apa yang ditanyakan, serta merumuskan jawaban sering dijumpai pada kegiatan pendidikan dasar, menengah dan tinggi. Pada hakekatnya, kegiatan ini adalah bentuk perumusan masalah (problem formulation) atau penstrukturan masalah (problem structuring). Pentingnya perumusan atau penstrukturan masalah dinyatakan oleh David Hilbert melalui ungkapannya "A perfect formulation of a problem is already half its solution" (Reid [1]).

Lalu apakah yang disebut dengan masalah itu sendiri? Terdapat banyak definisi masalah, namun pada hakekatnya, sesuatu itu dikatakan sebagai masalah ketika sekurang-kurangnya manusia menjawab "YA" terhadap salah satu dari ketiga pertanyaan berikut: Apakah sesuatu itu tidak disukai adanya? Apakah sesuatu itu ingin ditiadakan keberadaannya? Apakah sesuatu itu (berpotensi) menimbulkan kesulitan dan atau kerugian? (Prayitno [2]).

Berdasarkan tingkat kerumitannya, masalah terbagi kedalam masalah yang terstruktur dengan baik (well-defined problems), sehingga dapat diselesaikan dengan teknik penyelesaian masalah yang sederhana, serta masalah yang tidak terstruktur dengan baik (ill-structrured problems) yang memiliki karakteristik lebih kompleks dan sangat serius.

\footnotetext{
${ }^{1}$ Program Pasca Sarjana Doktor Ilmu Ekonomi, Universitas Katolik Parahyangan, Л. Merdeka No. 30, Bandung 40213, Indonesia. Email: iwanmuminbasarah@yahoo.com

2 Fakultas Teknologi Industri, Jurusan Teknik Industri, Universitas Katolik Parahyangan, Jl Ciumbuleuit 94, Bandung 40141, Indonesia. Email:ssusanto@unpar.ac.id

* Penulis korespondensi
}

Ciri-ciri permasalahan yang terstruktur dengan baik adalah dimilikinya kejelasan dalam ketiga aspek ciri permasalahan yang terstruktur dengan baik adalah dimilikinya kejelasan dalam ketiga aspek berikut ini: (i) kejelasan akan gambaran tentang keadaan sekarang, (ii) kejelasan akan gambaran tentang keadaan yang diharapkan, dan (iii) kejelasan tentang bagaimana cara untuk beranjak dari keadaan sekarang menuju keadaan yang diharapkan (Johns dan Sak [3]) dan (Basarah dan Susanto [4]). Permasalahan yang tidak terstruktur dengan baik adalah permasalahan yang tidak memenuhi sekurang-kurangnya satu dari ketiga aspek tersebut. Permasalahan yang tidak terstuktur, membutuhkan teknik atau metode khusus untuk penyelesaiannya.

Salah satu area yang didalamnya terdapat banyak permasalahan yang tidak terstrukur adalah manajemen rantai pasok (Supply Chain Management). Manajemen rantai pasok adalah metode atau pendekatan integratif untuk mengelola aliran produk, informasi dan uang secara terintegrasi yang melibatkan banyak pihak mulai dari hulu hingga hilir yang terdiri atas supplier, pabrik, jaringan distribusi maupun jasa-jasa logistik. (Pujawan [5]). Permasalahan manajemen rantai pasok bersifat (i) kompleks, (ii) seringkali tidak terstruktur, sehingga (iii) pemecahannya memerlukan pendekatan sistem (systems approach) (Pujawan [5]).

Apakah yang dimaksud dengan pernyataan "manajemen rantai pasok bersifat kompleks"? W.R. Ashby, salah satu tokoh Systems Thinking (berpikir system) seperti dikutip oleh Daellenbach mendefinisikan kompleksitas sebagai jumlah atau kuantitas informasi yang diperlukan untuk mendeskripsikan atau menggambarkan atau menyatakan sesuatu (Daellenbach et al., [6]). Bahwa manajemen rantai 
pasok bersifat kompleks, hal ini didukung oleh 3 pernyataan berikut. Pertama, pada hakekatnya masalah manajemen rantai pasok bersifat kompleks dan mengundang implikasi keputusan strategis jangka panjang (Ates and Cevik [7]). Kedua, masalah rantai pasok adalah salah satu masalah yang kompleks yang memerlukan prosedur pencarian solusi yang baru, karena ia menggabungkan beberapa submasalah yang berbeda, seperti distribusi, lokasi dan alokasi, transportasi, dan perencanaan produksi agar mengarah pada pemecahan masalah rantai pasok secara menyeluruh dalam kesatuan" (Gokhan et al., [8]). Ketiga, rantai pasok adalah jaringan entitas bisnis yang kompleks, mencakup aliran produk dan jasa, serta aliran keuangan dan informasi yang menyertainya, dari hulu ke hilir (Serdarasan [9]).

Bahwa masalah rantai pasok seringkali bersifat illstructured, hal ini didukung oleh 2 pernyataan berikut. Pertama, karena kompleksnya permasalahan logistik dan rantai pasok, sehingga permasalahan hulu dan hilir rantai pasokan dapat dikategorikan sebagai permasalahan yang tidak terstruktur. (Gupta dan Evans [10]). Kedua, desain strategi bisnis yang baru, inovasi untuk berkembang lebih baik, serta mengembangkan konsep dan penerapan rantai pasok yang baru, merupakan permasalahanpermasalahan yang komplek, tidak terstruktur dan merupakan tantangan bagi perusahaan untuk dapat menjadi keunggulan bersaing dengan kompetitornya(Baer et al., [11]).

Sebagai konsekuensi dari kompleksitas dan sifat illstructured yang melekat pada masalah manajemen rantai pasokan, maka penyelesaian masalah ini tak dapat lagi dilakukan secara parsial atau fragmentaris, melainkan memerlukan suatu pendekatan yang menyeluruh (holistic) yang dikenal sebagai pendekatan yang bersifat sistemik. Hal ini sejalan dengan 5 pernyataan berikut ini. Pertama, manajemen rantai pasok adalah seni dan ilmu pengetahuan tentang mengelola jaringan yang kompleks sehingga untuk dapat mengelolanya dengan baik satu sama lain, diperlukan pendekatan system (Cutting-Decelle et al., [12]). Kedua, because of the systems foundations of the quest for supply chain integration and because of the presumed interdependencies between the factors inhibiting that integration, a systems perspective is occupied (Bakker et al., [13]). Ketiga, pendekatan sistem untuk analisis rantai pasok dan meningkatkan kinerjanya, berdasar pada pemikiran bahwa penyelesaian harus dilakukan secara menyeluruh bukan parsial pada sub sistem yang ada (Sweeney [14, 15]). Keempat, salah satu yang menjadi kendala dalam operasionalisasi rantai pasok adalah ketidakhadiran sistem dalam pengelolaannya. Keadaan ini mengakibatkan pelak- sanaan manajemen rantai pasok yang tercerai-berai dan lemahnya integrasi antar rantai pasok (Szymczak, et al., [16]). Kelima, untuk dapat mengetahui titik-titik kegagalan dalam pelaksanaan rantai pasok, sistem dalam pengelolaan rantai pasok haruslah berdasar pada pemahaman yang menyeluruh tentang manajemen rantai pasok dan dapat mengakomodasi seluruh titik dalam jaringannya (Ghadge et al., [17]).

Penelitian ini bermula dari penelitian awal (Basarah dan Susanto [4]), dengan memasukkan 3 koreksi berikut. Pertama, pelaksanaan curah pendapat (brainstorming) ulang dengan menambah pemang$\mathrm{ku}$ kepentingan perusahaan sebagai partisipan, sehingga didapat narasi permasalahan yang baru. Kedua, pembentukan peta kognitif (cognitive map) yang baru. Ketiga, penerapan pendekatan SCA terhadap peta kognitif yang baru, sehingga didapatkan alternatif-alternatif solusi bagi akar permasalahan yang baru."

Terdapat 3 butir kontribusi dari penelitian yang dilakukan. Pertama, penelitian ini mengembangkan metode penstrukturan masalah untuk mengubah masalah yang semula bersifat tidak terstruktur menjadi masalah yang terstruktur. Metode yang dikembangkan secara fisik terdiri atas 9 (sembilan) langkah. Kedua, penelitian ini menunjukkan bahwa metode yang dikembangkan dapat diterapkan pada penstrukturan masalah manajemen rantai pasok di Perseroan Terbatas X, yang hasilnya adalah terpilihnya masalah prioritas utama. Ketiga, metode yang dikembangkan dapat memberi rekomendasi pemilihan satu opsi penyelesaian masalah, diantara sekian opsi-opsi lainnya yang teridenifikasi.

\section{Metode Penelitian}

\section{Soft Systems Thinking}

Pendekatan Hard Systems Thinking tidak diragukan lagi kontribusinya dalam pemecahan masalah operasional, namun disadari bahwa pendekatan ini perlu diimbangi atau dilengkapi dengan pendekatan Soft Systems Thinking. Pendekatan Soft System Thinking dipergunakan karena permasalahan yang dihadapi oleh manusia ternyata kompleks dan tidak terstruktur (Daellenbach et al., [6]). Masalah manajerial umumnya bersifat sistemik, dalam arti melibatkan interaksi dari banyak komponen sistem. Adapun setiap komponen sistem memiliki pemangku kepentingannya masing-masing, sehingga masalah manajerial akan melibatkan banyak pemangku kepentingan.

Soft System Thinking pertama kali dirintis sekitar tahun 1950 dengan konsep Gaming dari The Rand 
Corporatio Soft System Thinking dan telah mengalami perkembangan yang cukup pesat melalui kontribusi beberapa ilmuwan yang ahli dalam bidangnya seperti John Friend, Checklands, dan John Mingers dengan konsep Multimethodoolgy pada tahun 1995 (Daellenbach et al. [6]).

Salah satu pendekatan Soft System Thinking yang mengakomodasi wisdom dari banyak pemangku kepentingan dalam suatu organisasi adalah Strategic Choice Approach (SCA). SCA dikembangkan oleh John Friend dan Allen Hickling dengan bukunya yang terkenal yaitu Planning under Pressure: A Strategic Choice Approach. Berikut ini disampaikan garis besar dari metode SCA tersebut.

\section{Strategic Choice Approach}

Metode SCA dikembangkan untuk menyelesaikan permasalahan yang kompleks, tidak terstruktur dan memerlukan pendekatan sistem dalam penyelesaiannya. Penggalian informasi yang dibutuhkan dalam penerapan metode ini didapat dari suatu kelompok diskusi yang diisi oleh pemangku kepentingan dan orang-orang yang kompeten yang terlibat dalam permasalahan tersebut. Kelompok diskusi ini akan memformulasikan temuan-temuan dan hasil diskusi kelompok tersebut (Daellenbach et al. [6]). Tujuan metode SCA adalah untuk mendapatkan deskripsi sistem dari permasalahan yang ada, dengan mempertimbangkan berbagai macam sumber ketidakpastian, seperti ketidakpasian tentang hal teknis, politis, struktur, yang seringkali membuat suatu permasalahan menjadi sulit untuk dipecahkan (Mingers [18]). Metode SCA terdiri atas 4 modus yaitu shaping, designing, comparing dan choosing. Keempat modus ini bersifat komplementer serta dapat dijalankan secara fleksibel (Daellenbach et al. [6]). Pada modus shaping dilakukan pemilihan area keputusan dan fokus permasalahan (Friend dan Hickling [19]). Area keputusan pada hakekatnya adalah akar masalah dari keseluruhan permasalahan sistemik yang dihadapi. Fokus permasalahan pada hakekatnya adalah kumpulan area keputusan yang akan diselidiki lebih mendalam. Pada modus designing dilakukan identifikasi terhadap tindakan-tindakan apa saja yang dapat digunakan untuk memecahkan fokus permasalahan terpilih. Pada modus designing dilakukan penilaian kelayakan dari setiap kombinasi aksi untuk ditindaklanjuti. Pada modus comparing dilakukan perbandingan antar kombinasi aksi-aksi yang layak, yang dihasilkan dari modus designing. Dari hasil perbandingan pada modus comparing akan didapat kombinasi aksi terpilih, pemilihan inilah yang disebut dengan modus choosing yang akan disertai dengan paket-paket komitmen atau rencana kerja. Langkah kerja dalam metode SCA dapat dilihat pada Gambar 1.

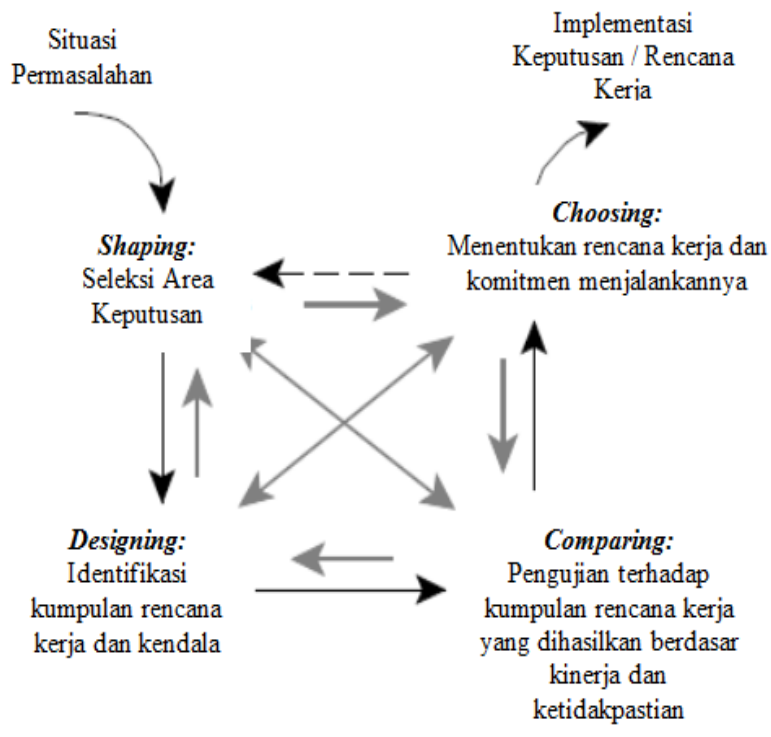

Gambar 1. Tahapan metode Strategic Choice Approach (Daellenbach et al. [6])

Metode SCA telah banyak digunakan oleh para peneliti dan praktisi antara lain meliputi (Friend dan Hickling [19]): (1) Penataan masa depan dari Notting Hill Carnival oleh Jonathan Rosenhead. (2) Penentuan prioritas dalam area kebijakan lingkungan oleh Frans Evers. (3) Pengembangan strategi pelayanan konsumen air oleh Richard Ormerod.

\section{Objek Penelitian}

Objek penelitian adalah Perseroan Terbatas X, suatu perusahaan manufaktur dan distribusi pelapis dan kimia bangunan yang memiliki kantor pusat di kota Bandung dengan 30 kantor cabang di seluruh Indonesia. Jumlah tenaga kerja yang ada saat ini sekitar 2000 orang. Jumlah karyawan tersebut terdiri atas sekitar 800 orang tenaga kerja tetap, dan sekitar 1200 orang tenaga kerja waktu tertentu. Pengelolaan rantai pasok pada perusahaan ini dikelola oleh Divisi Supply Chain Management, yang membawahi 6 (enam) department yaitu department procurement, warehouse, production, inventory, transportation dan department customer accomodation

\section{Hasil dan Pembahasan}

\section{Usulan Metode Penstrukturan Masalah di PT $\mathrm{X}$ dan Ilustrasi Penerapannya}

Penelitian ini mengusulkan penggunaan cognitive map dan SCA sebagai basis dari pengembangan metode penstrukturan masalah yang diusulkan. Usulan lainnya adalah perumusan 9 (sembilan) langkah, yang terkait satu sama lain, bagi metode penstrukturan masalah ini. Kesembilan langkah yang terkait satu sama lain adalah sebagai berikut: 
Langkah-1. Memilih fasilitator yang akan memandu jalannya diskusi dan membentuk focus group discussion dalam perusahaan untuk mendapatkan informasi yang komprehensif tentang permasalahan yang dihadapi;

Langkah-2. Melakukan brainstorming yang berkaitan dengan masalah terkait, sehingga dihasilkan suatu narasi atau deskripsi dari permasalahan yang sedang dihadapi;

Langkah-3. Membuatan peta kognitif berdasar pada hasil narasi permasalahan yang dihasilkan pada Langkah-2;

Langkah-4. Mengidentifikasi akar masalah pada peta kognitif yang dihasilkan pada Langkah-3, sebagai masukan untuk metode SCA;

Langkah-5. Menggali opini peserta diskusi kelompok untuk memberikan hubungan antar akar masalah yang telah diidentifikasi pada Langkah 4 (proses ini disebut shaping);

Langkah-6. Menentuan fokus masalah hubungan antar akar masalah yang telah dihasilkan pada Langkah-5;

Langkah-7. Menghasilkan pilihan-pilihan keputusan berdasar kombinasi fokus masalah yang dihasilkan pada Langkah-6, sehingga didapat matriks keputusan (proses ini disebut designing);

Langkah-8. Melakukan perbandingan antar pilihanpilihan keputusan yang dihasilkan pada Langkah-7 (proses ini disebut comparing) hingga didapat pilihan keputusan yang memungkinkan untuk dilaksanakan, dengan mempertimbangkan keadaan perusahaan saat ini. Perbandingan ini didasarkan pada besaran yang disebut skor total keseluruhan; Langkah-9. Berdasarkan skor total keseluruhan untuk setiap pilihan keputusan yang dihasilkan pada Langkah-8, kelompok diskusi merekomendasikan pilihan keputusan dengan skor total keseluruhan terbesar sebagai pilihan keputusan yang akan dijalankan (proses ini disebut choosing).

Berikut ini adalah ilustrasi penerapan usulan metode penstrukturan masalah pengelolaan rantai pasokan dengan metode SCA berbasis peta kognitif pada Perseroan Terbatas X.

\section{Hasil Eksekusi Langkah-1:}

Fasilitator yang dipilih adalah peneliti, yaitu Iwan Mu'min Basarah, yang juga adalah karyawan dari department human capital strategic di perusahaan. Peserta diskusi kelompok dipilih atas dasar kepentingan terhadap permasalahan yang dihadapi. Kompetensi anggota kelompok dipastikan sesuai dengan bidang yang dikuasainya. Peserta kelompok diskusi yang telah ditunjuk itu adalah kepala-kepala dari divisi supply chain management, selling and marketing, kepala department national sales, inventory, warehouse, transportation, customer acco- modation, human capital operational, dan kepala bagian learning and development.

\section{Hasil Eksekusi Langkah-2:}

Masukan bagi Langkah-2 ini adalah informasi dari setiap peserta diskusi. Setiap peserta diskusi menyampaikan sudut pandangnya atas permasalahan yang sedang dihadapi perusahaan berdasarkan posisi mereka dalam organisasi. Dinamika kelompok yang muncul dalam langkah ini dicermati dengan baik oleh fasilitator dan ditulis kembali sehingga menjadi suatu narasi permasalahan.

Narasi permasalahan inilah yang merupakan keluaran dari Langkah-2 ini. Setiap kalimat yang menjadi bagian dari narasi ini diberi notasi atau penomoran pernyataan. Penomoran ini ditujukan bagi kemudahan penyusunan peta kognitif kelak pada Langkah-3. Narasi permasalahan yang telah terbentuk disampaikan kembali kepada anggota kelompok untuk mendapatkan persetujuan.

\section{Hasil Eksekusi Langkah-3:}

Pada langkah ini fasilitator meminta anggota kelompok untuk melihat keterkaitan atau hubungan kausal atau hubungan sebab-akibat antar pernyataan pada narasi permasalahan. Hubungan ini dinyatakan dengan simbol panah berarah. Pangkal panah menyatakan pernyataan yang menjadi penyebab. Ujung panah menyatakan pernyataan akibat. Keluaran dari langkah ini adalah peta kognitif seperti yang terlihat pada Gambar-2. Sebagai catatan, beberapa ikon pada peta kognitif disertai simbol lingkaran, hal ini sebenarnya merupakan hasil dari Langkah-4 yang akan diterangkan lebih lanjut pada bahasan langkah tersebut.

\section{Hasil Eksekusi Langkah-4:}

Keluaran dari langkah ini adalah didapatkannya sekelompok akar masalah. Sekelompok akar masalah diperoleh dari peta kognitif dengan jalan mencari pernyataan yang secara grafis tak pernah ditusuk oleh sebuah panahpun, artinya tak dipengaruhi oleh pernyataan lain. Akar masalah inilah yang pada Gambar 2 diberi simbol lingkaran, seperti telah diulas pada pembahasan hasil eksekusi Langkah-3. Sekelompok akar masalah yang didapat adalah (lihat Gambar-1): Tingginya biaya persediaan bahan baku; Tingginya biaya persediaan barang jadi;Tingginya biaya transportasi ke kantor cabang; Tingginya biaya transportasi ke konsumen; Rendahnya kompetensi tenaga kerja yang terlibat dalam pengelolaan rantai pasokan, serta. Belum berjalannya pengembangan kompetensi kepada karyawan yang terlibat dalam proses rantai pasokan secara keseluruhan. 


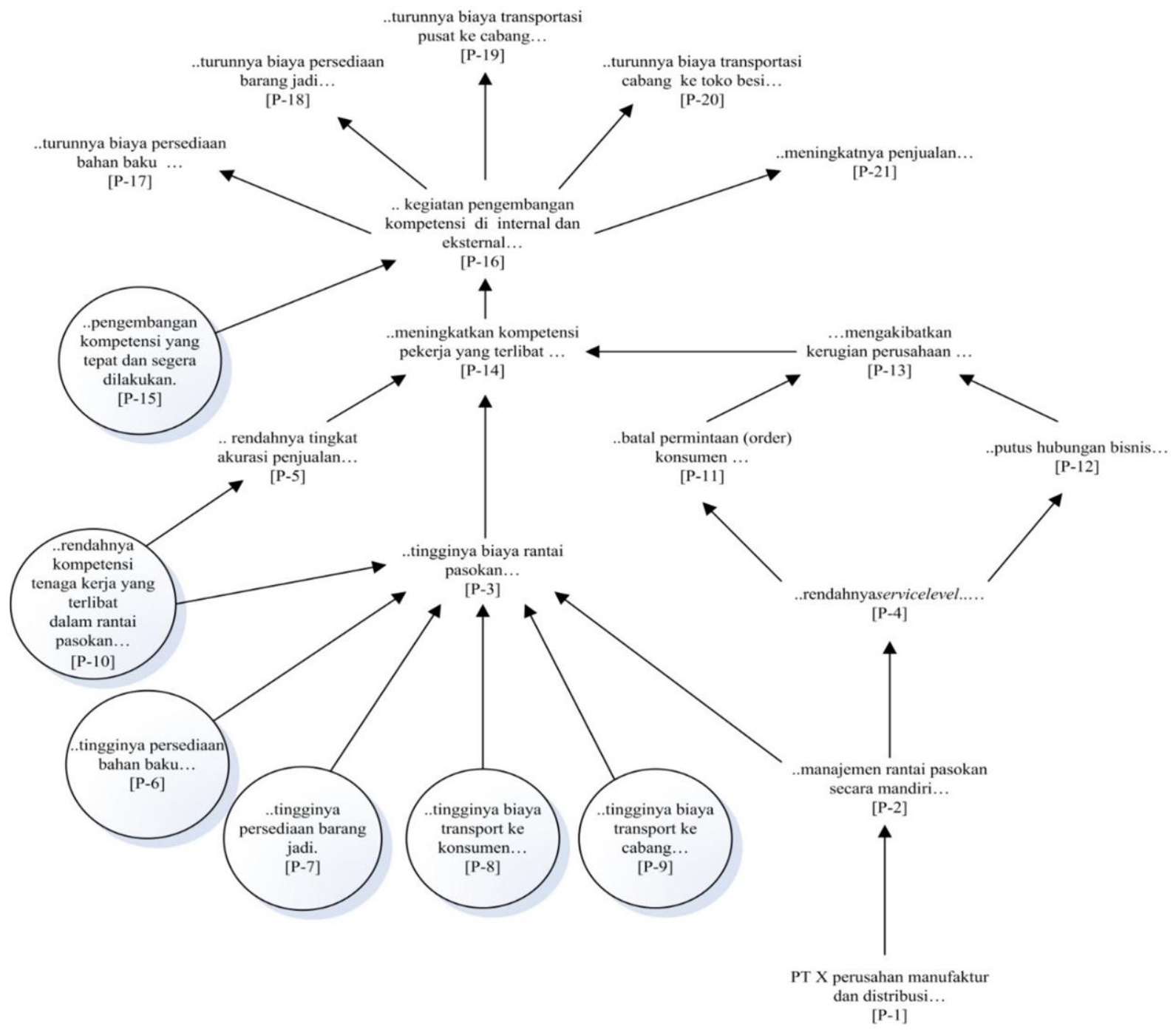

Gambar 2. Peta kognitif dari permasalahan rantai pasokan di Perseoran Terbatas X

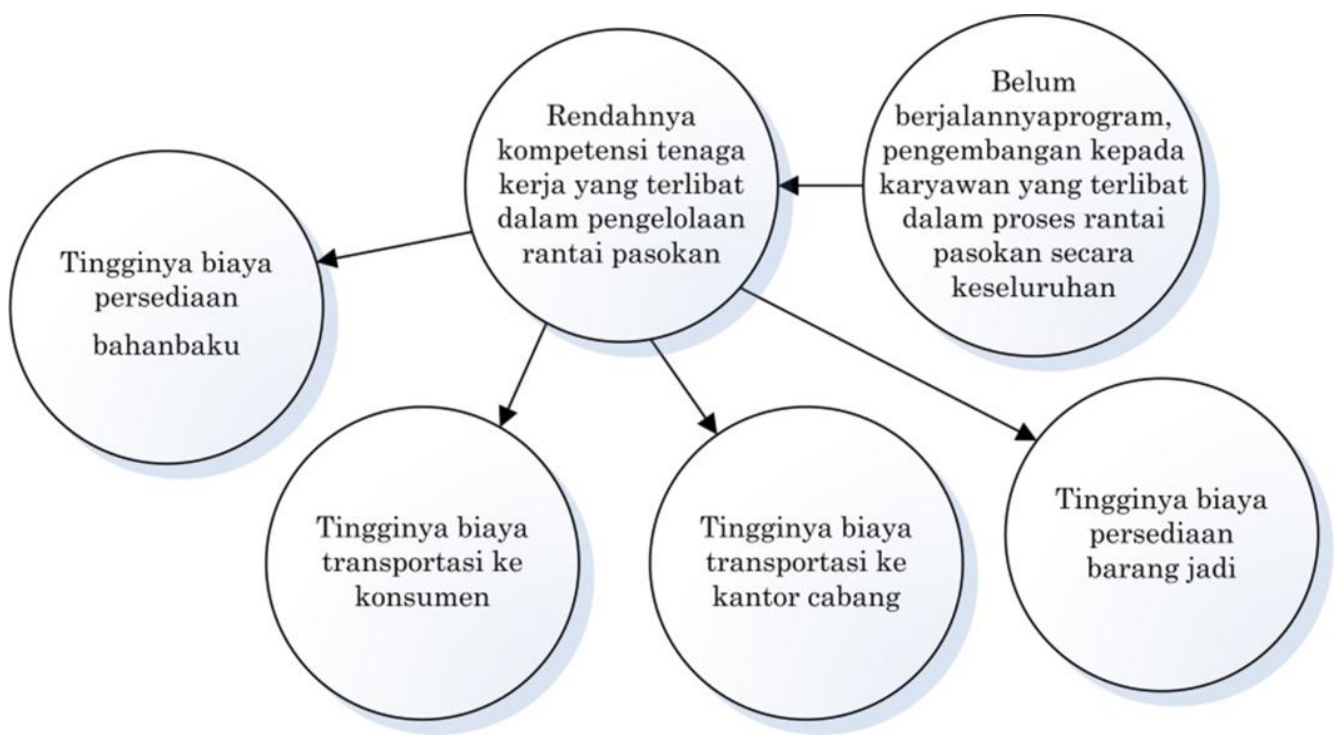

Gambar 3. Hubungan antar akar masalah pengelolaan rantai pasokan di Perseroan Terbatas X. 


\section{Hasil Eksekusi dari Langkah 5:}

Diskusi kelompok dilakukan untuk menentukan hubungan antar akar masalah yang telah dihasilkan pada Langkah 4. Proses diskusi ini bertujuan untuk mengetahui hubungan sebab-akibat atau keterkaitan, baik langsung maupun tidak langsung, antar akar masalah tersebut. Akar masalah dilambangkan dengan lingkaran dan dua akar masalah yang memiliki hubungan sebab-akibat dihubungkan dengan tanda panah berarah. Dua akar masalah dikategorikan sebagai memiliki hubungan sebab-akibat bila terdapat bangunan silogisme yang bermula dari sebab dan berakhir pada akibat. Silogisme adalah adalah suatu argumen yang terdiri atas premis-premis-premis

A mengakibatkan B

B mengakibatkan C

yang darinya dapat diturunkan konklusi atau kesimpulan:

A mengakibatkan $\mathrm{C}$

Berikut ini adalah beberapa silogisme yang didapat dari diskusi kelompok tersebut.

\section{Silogisme 1.}

Rendahnya kompetensi tenaga kerja yang terlibat dalam pengelolaan rantai pasok (khususnya kompetensi dalam perencanaan produksi) mengakibatkan terjadinya banyak kesalahan dalam penjadwalan proses produksi. Terjadinya banyak kesalahan dalam penjadwalan proses produksi mengakibatkan banyaknya kesalahan perencanaan kebutuhan bahan baku. Banyaknya kesalahan perencanaan kebutuhan bahan baku mengakibatkan banyaknya kesalahan pada penjadwalan pembelian bahan baku. Banyaknya kesalahan pada penjadwalan pembelian bahan baku mengakibatkan banyaknya terjadi kesalahan pembelian bahan baku. Banyaknya terjadi kesalahan pembelian bahan baku mengakibatkan banyaknya kedatangan bahan baku yang tidak dibutuhkan untuk proses produksi. Banyaknya kedatangan bahan baku yang tidak dibutuhkan mengakibatkan tingginya persediaan bahan baku di gudang bahan baku. Tingginya biaya persediaan bahan baku di gudang bahan baku mengakibatkan tingginya persediaan bahan baku di gudang tersebut.

Berdasarkan sekumpulan premis ini, maka dengan prinsip silogisme, didapatkan hubungan sebabakibat yang pertama (sebagai salah satu keluaran dari Langkah-5 ini), yaitu rendahnya kompetensi tenaga kerja yang terlibat dalam pengelolaan rantai pasok mengakibatkan tingginya biaya persediaan bahan baku di gudang bahan baku.

\section{Silogisme 2.}

Rendahnya kompetensi tenaga kerja dalam pengelolaan rantai pasok mengakibatkan banyaknya terjadi kesalahan pada perencanaan kebutuhan persediaan barang jadi di kantor cabang penjualan. Banyaknya terjadi kesalahan pada perencanaan kebutuhan persediaan barang jadi di kantor cabang penjualan mengakibatkan banyaknya kesalahan informasi yang disampaikan ke gudang kantor pusat untuk pengiriman barang jadi ke kantor cabang. Banyaknya kesalahan informasi kebutuhan barang jadi yang akan dikirimkan ke kantor cabang mengakibatkan banyaknya kesalahan pengiriman barang jadi ke gudang kantor cabang. Banyaknya kesalahan pengiriman barang jadi ke gudang kantor cabang mengakibatkan banyaknya pengiriman barang yang sebenarnya tidak dibutuhkan di gudang kantor cabang. Banyaknya pengiriman barang yang sebenarnya tidak dibutuhkan di gudang kantor cabang mengakibatkan tingginya persediaan barang jadi di gudang kantor cabang. Tingginya persediaan barang jadi di gudang kantor cabang mengakibatkan tingginya biaya persediaan barang jadi di gudang tersebut.

Berdasarkan sekumpulan premis ini, maka dengan prinsip silogisme, didapatkan hubungan sebabakibat yang kedua (sebagai salah satu keluaran dari Langkah-5 ini), yaitu rendahnya kompetensi tenaga kerja yang terlibat dalam pengelolaan rantai pasok mengakibatkan tingginya biaya persediaan barang jadi di gudang kantor cabang.

\section{Silogisme 3.}

Rendahnya kompetensi tenaga kerja yang terlibat dalam pengelolaan rantai pasok akan mengakibatkan sering terjadinya kesalahan pada perencanaan kebutuhan persediaan barang jadi di kantor cabang penjualan. Sering terjadinya kesalahan pada perencanaan kebutuhan persediaan barang jadi di kantor cabang penjualan mengakibatkan banyaknya kesalahan informasi yang disampaikan ke gudang kantor pusat untuk pengiriman barang jadi ke kantor cabang. Banyaknya kesalahan informasi yang disampaikan ke gudang kantor pusat untuk pengiriman barang jadi kekantor cabang mengakibatkan banyaknya kesalahan pengiriman barang jadi ke kantor cabang. Banyaknya kesalahan pengiriman barang jadi ke kantor cabang mengakibatkan banyaknya pengiriman barang yang sebenarnya tidak dibutuhkan di gudang kantor cabang. Banyaknya pengiriman barang yang sebenarnya tidak dibutuhkan di gudang kantor cabang menyebabkan tingginya biaya transportasi pengiriman barang jadi dari gudang kantor pusat ke gudang kantor cabang.

Berdasarkan sekumpulan premis ini, maka dengan prinsip silogisme, didapatkan hubungan sebab-akibat yang ketiga (sebagai salah satu keluaran dari Langkah-5 ini), yaitu rendahnya kompetensi tenaga kerja yang terlibat dalam pengelolaan rantai pasok 
mengakibatkan tingginya biaya transportasi pengiriman barang jadi dari gudang kantor pusat ke gudang kantor cabang.

\section{Silogisme 4.}

Rendahnya kompetensi tenaga kerja yang terlibat dalam pengelolaan rantai pasok khususnya tenaga administrasi pergudangan di kantor cabang penjualan dalam melakukan penyusunan rencana pengiriman ke toko besi akan mengakibatkan kesalahan dalam penyusunan rute kirim ke toko. Kesalahan dalam penyusunan rute kirim ke toko akan mengakibatkan pengiriman yang tidak berurutan. Pengiriman yang tidak berurutan akan mengakibatkan tingginya kebutuhan bahan bakar yang dipergunakan untuk pengiriman. Tingginya kebutuhan bahan bakar yang dipergunakan akan membuat tingginya biaya bahan bakar. Tinggnya biaya bahan bakar akan menyebabkan tingginya biaya transportasi dari gudang kantor cabang ke konsumen atau toko besi.

Berdasarkan sekumpulan premis ini, maka dengan prinsip silogisme, didapatkan hubungan sebab-akibat yang keempat (sebagai salah satu keluaran dari Langkah-5 ini), yaitu rendahnya kompetensi tenaga kerja yang terlibat dalam pengelolaan rantai pasokan mengakibatkan tingginya biaya transportasi pengiriman barang jadi dari gudang kantor cabang ke konsumen.

\section{Silogisme 5.}

Belum berjalannya program pengembangan kompetensi kepada karyawan yang terlibat dalam pengelolaan rantai pasok mengakibatkan tidak tersampaikannya materi-materi pelatihan yang seharusnya telah diterima oleh tenaga kerja yang terlibat dalam pengelolaan rantai pasok. Tidak tersampaikannya materi pelatihan tentang pengelolaan rantai pasok kepada tenaga kerja yang terlibat akan mengakibatkan rendahnya kompetensi tenaga kerja yang terlibat dalam pengelolaan rantai pasok.

Berdasarkan sekumpulan premis ini, maka dengan prinsip silogisme, didapatkan hubungan sebab-akibat yang kelima (sebagai salah satu keluaran dari Langkah-5 ini), yaitu belum berjalannya pelatihan kepada karyawan yang terlibat dalam pengelolaan rantai pasok mengakibatkan rendahnya kompetensi tenaga kerja yang terlibat dalam pengelolaan rantai pasok.

Kelima hasil silogisme dapat dinyatakan dalam Gambar 3 yang menyatakan hubungan sebab-akibat antar akar masalah yang berhasil diidentifikasi pada Langkah-4.

\section{Hasil Eksekusi dari Langkah 6:}

Keluaran dari langkah ini adalah fokus masalah. Untuk mendapatkan akar masalah yang akan menjadi fokus masalah, diusulkan aturan sederhana (rule of thumbs) sebagai berikut: (i) Urutkan akar masalah dimulai dengan akar masalah yang paling banyak memiliki kaitan dengan akar masalah yang lain; (ii) Pilihlah akar-akar masalah yang memiliki banyak kaitan dengan akar masalah lain sebagai fokus masalah; (iii) Bila akar masalah yang terpilih pada (ii) pun memiliki akar masalah penyebabnya, maka akar masalah penyebab inipun menjadi focus masalah.

Penerapan rule of thumbs (i) terhadap Gambar 3 yang dihasilkan pada Langkah-5 akan menghasilkan informasi bahwa masalah "Belum berjalannya program pengembangan kepada karyawan yang terlibat dalam proses rantai pasok" memiliki kaitan paling banyak dengan akar masalah lainnya yaitu sebanyak 4 akar masalah lainnya, sehingga berdasar kaidah (ii) ia menjadi fokus masalah. Akar masalah "Belum berjalannya pelatihan kepada karyawan yang terlibat dalam proses rantai pasok secara keseluruhan" hanya memiliki kaitan dengan satu akar masalah lainnya, maka berdasar butir (iii) hal ini pun dapat menjadi fokus masalah.

Jadi, yang menjadi keluaran dari Langkah-6 ini adalah fokus masalah yaitu "Rendahnya kompetensi tenaga kerja yang terlibat dalam pengelolaan rantai pasokan" dan "Belum berjalannya pengembangan kompetensi karyawan yang terlibat dalam proses rantai pasokan". Kedua fokus masalah terpilih ini disebut Decision Area dari metode penstrukturan masalah yang tengah dibahas.

\section{Hasil Eksekusi dari Langkah 7:}

Berdasarkan kedua fokus masalah ini, maka anggota diskusi diminta untuk merumuskan alternatif pemecahan masalah bagi setiap fokus masalah tersebut. Sebagai langkah awal, untuk mendapatkan alternatif pemecahan masalah, anggota kelompok diskusi diminta untuk mengidentifikasi faktor faktor yang menjadi penyebab munculnya masalah tersebut. Untuk masalah "Rendahnya kompetensi tenaga kerja yang terlibat dalam pengelolaan rantai pasokan", anggota kelompok diskusi berhasil mengidentifikasi penyebabnya yaitu: (i) Sejak direkrut, karyawan belum pernah diberi pelatihan tentang pengelolaan rantai pasok; (ii) Penempatan karyawan yang tidak tepat pada posisi dan kompetensinya, mengakibatkan kompetensi karyawan tersebut rendah untuk area pengelolaan rantai pasokan; (iii) Program pengembangan karyawan di area pengelolaan rantai pasok yang tidak berkelanjutan. 
Dari hasil diskusi kelompok, diperoleh alternatif pemecahan masalah "Rendahnya kompetensi tenaga kerja yang terlibat dalam pengelolaan rantai pasokn", sebagai berikut: (i) Diberikan pelatihan dasar tentang pengelolaan rantai pasok bagi karyawan yang berada di area pekerjaaan pengelolaan rantai pasok; (ii) Dilakukan rotasi dan mutasi kepada karyawan yang tidak tepat penempatannya; (iii) Disusun program pengembangan yang berkelanjutan dan dipastikan evaluasi program pengembangannya dilakukan secara berkelanjutan juga.

Untuk fokus masalah "Belum berjalannya program pengembangan kepada karyawan yang terlibat dalam proses rantai pasok dan penjualan", anggota kelompok diskusi berhasil mengidentifikasi penyebabnya yaitu: (i) Karyawan yang bersangkutan tidak mendapatkan ijin dari atasan untuk mengikuti program pengembangan dengan alasan sibuk dengan pekerjaan operasionalnya; (ii) Keterbatasan fasilitator yang memiliki kompetensi dalam menyampaikan materi yang diinginkan.

Dari hasil diskusi kelompok, diperoleh alternatif pemecahan masalah "Belum berjalannya program pengembangan kepada karyawan yang terlibat dalam proses rantai pasok dan penjualan" berikut: (i) Memberikan pengertian dan koordinasi kepada atasan terkait pentingnya pengembangan karyawan secara keseluruhan untuk meningkatkan kinerja karyawan tersebut dan kinerja perusahaan secara keseluruhan walaupun kondisi operasional pekerjaannya sangat sibuk; (ii) Berkoordinasi dan bekerjasama dengan fasilitator eksternal dan atau konsultan untuk menjadi fasilitator yang bisa memberikan pelatihan dan pengembangan kepada karyawan.

Jika disusun dalam bentuk matriks, maka akan diperoleh alternatif solusi dari pemecahan masalah seperti dinyatakan pada Tabel 1. Keluaran dari Langkah-7 adalah pilihan-pilihan keputusan yang bisa diambil sebagai berikut: (i) Koordinasi dengan atasan karyawan yang bersangkutan untuk diberikan pelatihan dasar tentang pengelolaan rantai pasok bagi karyawan baru yang berada di area pekerjaaan pengelolaan rantai pasok; (ii) Koordinasi dengan atasan karyawan yang bersangkutan untuk melakukan rotasi dan mutasi kepada karyawan yang tidak tepat penempatannya; (iii) Koordinasi dengan atasan karyawan yang bersangkutan untuk menyusun program pengembangan yang berkelanjutan dan dipastikan evaluasi program pengembangannya dilakukan secara berkelanjutan juga; (iv) Bekerjasama dengan fasilitator eksternal dan atau konsultan untuk memberikan pelatihan dasar tentang pengelolaan rantai pasok bagi karyawan baru yang berada di area pekerjaaan pengelolaan

Tabel 1. Matriks pilihan-pilihan keputusan penyelesaian permasalahan rantai pasokan

\begin{tabular}{|c|c|c|c|}
\hline & & \multicolumn{2}{|c|}{$\begin{array}{c}\text { Belum berjalannya Program Pengembangan Karyawan yang terlibat } \\
\text { dalam pengelolaan rantai pasok dan penjualan }\end{array}$} \\
\hline & & $\begin{array}{l}\text { Koordinasi dengan atasan } \\
\text { karyawan yang bersangkutan }\end{array}$ & $\begin{array}{l}\text { Bekerjasama dengan fasilitator } \\
\text { eksternal dan atau konsultan }\end{array}$ \\
\hline \multirow[t]{3}{*}{$\begin{array}{l}\text { Rendahnya } \\
\text { Kompetensi } \\
\text { karyawan yang } \\
\text { terlibat dalam } \\
\text { pengelolaan } \\
\text { rantai pasok }\end{array}$} & $\begin{array}{l}\text { Diberikan pelatihan dasar } \\
\text { tentang pengelolaan } \\
\text { rantai pasokan bagi } \\
\text { karyawan yang berada di } \\
\text { area pekerjaaan } \\
\text { pengelolaan rantai pasok. }\end{array}$ & $\begin{array}{l}\text { Koordinasi dengan atasan } \\
\text { karyawan yang bersangkutan } \\
\text { untuk diberikan pelatihan dasar } \\
\text { tentang pengelolaan rantai pasok } \\
\text { bagi karyawan yang berada di } \\
\text { area pekerjaaan pengelolaan } \\
\text { rantai pasok. }\end{array}$ & $\begin{array}{l}\text { Bekerjasama dengan fasilitator } \\
\text { eksternal dan atau konsultan } \\
\text { untuk memberikan pelatihan } \\
\text { dasar tentang pengelolaan } \\
\text { rantai pasok bagi karyawan } \\
\text { yang berada di area pekerjaaan } \\
\text { pengelolaan rantai pasok. }\end{array}$ \\
\hline & $\begin{array}{l}\text { Dilakukan rotasi dan } \\
\text { mutasi kepada karyawan } \\
\text { yang tidak tepat } \\
\text { penempatannya. }\end{array}$ & $\begin{array}{l}\text { Koordinasi dengan atasan } \\
\text { karyawan yang bersangkutan } \\
\text { untuk melakukan rotasi dan } \\
\text { mutasi kepada karyawan yang } \\
\text { tidak tepat penempatannya. }\end{array}$ & $\begin{array}{l}\text { Bekerjasama dengan fasilitator } \\
\text { eksternal dan atau konsultan } \\
\text { melakukan rotasi dan mutasi } \\
\text { kepada karyawan yang tidak } \\
\text { tepat penempatannya. }\end{array}$ \\
\hline & $\begin{array}{l}\text { Disusun program } \\
\text { pengembangan yang } \\
\text { berkelanjutan dan } \\
\text { dipastikan evaluasi } \\
\text { program pengem- } \\
\text { bangannya dilakukan } \\
\text { secara berkelanjutan } \\
\text { juga. }\end{array}$ & $\begin{array}{l}\text { Koordinasi dengan atasan } \\
\text { karyawan yang bersangkutan } \\
\text { untuk menyusun program } \\
\text { pengembangan yang } \\
\text { berkelanjutan dan dipastikan } \\
\text { evaluasi program pengem- } \\
\text { bangannya dilakukan secara } \\
\text { berkelanjutan juga. }\end{array}$ & $\begin{array}{l}\text { Bekerjasama dengan fasilitator } \\
\text { eksternal dan atau konsultan } \\
\text { untuk menyusun program } \\
\text { pengembangan yang berkelan- } \\
\text { jutan dan dipastikan evaluasi } \\
\text { program pengembangannya } \\
\text { dilakukan secara berkelanjutan } \\
\text { juga. }\end{array}$ \\
\hline
\end{tabular}


rantai pasok; (v) Bekerjasama dengan fasilitator eksternal dan atau konsultan melakukan rotasi dan mutasi kepada karyawan yang tidak tepat penempatannya; (vi) Bekerjasama dengan fasilitator eksternal dan atau konsultan untuk menyusun program pengembangan yang berkelanjutan dan dipastikan evaluasi program pengembangannya dilakukan secara berkelanjutan juga.

\section{Hasil Eksekusi dari Langkah 8:}

Dalam proses membandingkan pilihan keputusan yang akan diambil, pertama-tama para peserta diskusi kelompok secara bersama-sama menentukan kriteria yang akan digunakan dalam memilih pilihan keputusan tersebut. Kriteria yang dihasilkan adalah:

Kriteria-1: Efektifitas keputusan yang akan diambil berkaitan dengan dampak hasil pengembangan; Kriteria-2: Kondisi keuangan perusahaan.

Berdasar hasil diskusi kelompok dan dengan mengikuti langkah-langkah pada metode The Analytical Hierarchy Process dari Thomas Saaty (Winston [20]) didapatkan 3 hasil berikut.

Dari hasil wawancara dengan para stakeholder didapatkan matrix reciprocal dari AHP sebagai berikut: $A=\left[\begin{array}{cc}1 & 1 / 3 \\ 3 & 1\end{array}\right]$. Normalisasi dari matrix A menghasilkan $A_{\text {norm }}$ sebagai berikut:

$A_{\text {norm }}=\left[\begin{array}{cc}\frac{1}{1+3} & \frac{1 / 3}{\frac{1}{3}+1} \\ \frac{3}{1+3} & \frac{1}{3}+1\end{array}\right]=\left[\begin{array}{ll}0,250 & 0,248 \\ 0,750 & 0,752\end{array}\right]$

Estimasi dari bobot untuk setiap objective adalah sebagai berikut:

$w_{1}=\frac{0,250+0,248}{2}=0,249 ; w_{2}=\frac{0,750+0,752}{2}=0.751$

sehingga didapat matriks berikut:

$$
w=[0,249 \quad 0,751]
$$

Selanjutnya ditentukan skor dari setiap alternatif untuk setiap objective:

Skor dari alternatif Pilihan-i hingga Pilihan-vi untuk objective Effektivitas

Skor dari alternatif Pilihan-i hingga Pilihan-vi untuk objective Keuangan

Sebagai ilustrasi akan ditentukan skor dari Pilihan$i$, Pilihan-ii, hingga Pilihan-vi untuk objective Effektivitas.

Pertama-tama lakukan wawancara dengan para stakeholder untuk mendapatkan the pairwise comparison matrix for alternatives untu objective Effektivitas, misalkan hasilnya adalah:

$B=\left[\begin{array}{cccccc}1 & 0,20 & 0,33 & 0,33 & 0,50 & 0,50 \\ 5 & 1 & 0,50 & 1 & 1 & 1 \\ 3 & 2 & 1 & 0,33 & 0,50 & 0,50 \\ 3 & 1 & 3 & 1 & 1 & 1 \\ 2 & 1 & 2 & 1 & 1 & 1 \\ 2 & 1 & 2 & 1 & 1 & 1\end{array}\right]$

Selanjutnya dapatkan matriks $B_{\text {norm }}$ berikut ini: $B_{\text {norm }}$

$=\left[\begin{array}{llllll}0,063 & 0,032 & 0,038 & 0,071 & 0,100 & 0,100 \\ 0,313 & 0,161 & 0,057 & 0,214 & 0,214 & 0,200 \\ 0,188 & 0,323 & 0,113 & 0,071 & 0,100 & 0,100 \\ 0,188 & 0,161 & 0,340 & 0,214 & 0,200 & 0,200 \\ 0,125 & 0,161 & 0,226 & 0,214 & 0,200 & 0,200 \\ 0,125 & 0,161 & 0,226 & 0,214 & 0,200 & 0,200\end{array}\right]$

dengan merata-ratakan setiap baris dari matriks $B_{\text {norm }}$ didapat matriks $\mathbf{u}$ berikut ini:

$$
\begin{aligned}
& u_{1} \\
& =\left[\begin{array}{llllll}
0,067 & 0,191 & 0,149 & 0,217 & 0,188 & 0,188
\end{array}\right]
\end{aligned}
$$

Dengan cara yang sama dilakukan wawancara untuk menentukan bobot untuk objective Keuangan, dan hasilnya

$$
\begin{aligned}
& \boldsymbol{u}_{2} \\
& =
\end{aligned}\left[\begin{array}{llllll}
0,033 & 0,129 & 0,185 & 0,102 & 0,114 & 0,138
\end{array}\right]
$$

Skor Keseluruhan (Overall Score) untuk alternatif ke-j adalah $\sum_{i=1}^{n} w_{i} u_{i j}$,

$n$ adalah banyaknya obyektive, dan $w_{i}$ adalah bobot untuk obyektive ke $i$ dam $u_{i j}$ adalah skor dari objective ke $i$, alternative ke-j (lihat Tabel 2.)

Berdasarkan perolehan kedua hasil sebelumnya, didapatkan hasil ketiga berikut ini berupa skor total (stotal) sebagai berikut:

stotal Pilihan-I $=(0,248)(0,067)+(0,752)(0,333)=0,267$

stotal Pilihan-ii $=(0,248)(0,191)+(0,752)(0,129)=0,144$ stotal Pilihan-iii $=(0,248)(0,149)+(0,752)(0,185)=0,176$ stotal Pilihan-iv $=(0,248)(0,217)+(0,752)(0,102)=0,131$ stotal Pilihan-v $=(0,248)(0,188)+(0,752)(0,113)=0,132$ stotal Pilihan-vi $=(0,248)(0,188)+(0,752)(0,138)=0,150$

Skor total untuk setiap pilihan keputusan ini yang menjadi keluaran dari Langkah-8.

Tabel 2. Bobot kedua kriteria untuk setiap pilihan keputusan

\begin{tabular}{lcc}
\hline & Bobot kriteria-1 & Bobot kriteria-2 \\
\hline Pilihan-i & 0,067 & 0,333 \\
Pilihan-ii & 0,191 & 0,129 \\
Pilihan-iii & 0,149 & 0,185 \\
Pilihan-iv & 0,217 & 0,102 \\
Pilihan-v & 0,188 & 0,113 \\
Pilihan-vi & 0,188 & 0,138 \\
Total & 1,000 & 1,000 \\
\hline
\end{tabular}


Tabel 3. The uncertainty area pada permasalahan rantai pasokan Perseroran Terbatas X

\begin{tabular}{|c|c|c|}
\hline No & Uncertainty area & $\begin{array}{c}\text { Type of } \\
\text { uncertainty }\end{array}$ \\
\hline 1 & $\begin{array}{l}\text { Atasan karyawan yang bersangkutan ti- } \\
\text { dak memiliki waktu untuk diajak ber- } \\
\text { diskusi dan berkoordinasi dalam hal } \\
\text { pengembangan karyawan }\end{array}$ & UE \\
\hline 2 & $\begin{array}{l}\text { Oleh karena satu dan lain kesibukan, } \\
\text { karyawan yang bersangkutan tidak } \\
\text { memiliki waktu untuk mengikuti } \\
\text { kegiatan pengembangan. }\end{array}$ & UR \\
\hline 3 & $\begin{array}{l}\text { Atasan karyawan yang bersangkutan } \\
\text { tidak memiliki waktu untuk bekerja } \\
\text { bersama menyusun program } \\
\text { pengembangan bagi karyawan }\end{array}$ & UE \\
\hline 4 & $\begin{array}{l}\text { Atasan karyawan yang bersangkutan } \\
\text { tidak memiliki kompetensi dalam } \\
\text { menyusun program pengembangan bagi } \\
\text { karyawan }\end{array}$ & UV \\
\hline
\end{tabular}

Berdasarkan 2 pillihan keputusan dengan nilai tertinggi yang diperoleh yaitu Pilihan ke-i dan Pilihan ke-iii, maka selanjutnya dilakukan analisis the uncertainty area.

The uncertainty area (UA) adalah deskripsi dari setiap sumber ketidakpastian yang mungkin muncul dan mengakibatkan kesulitan dalam penentuan penyelesaian permasalahan. (Friend dan Hickling [19]). Dalam menentukan the uncertainty area dari permasalahan pengelolaan rantai pasokan yang dihadapi oleh Perseroan Terbatas X ini, fasilitator mengajak anggota kelompok untuk berdiskusi mengenai kemungkinan-kemungkinan ketidakpastian yang akan muncul berkaitan dengan pelaksanaan 2 pilihan keputusan yang diambil. Hasil diskusi tersebut dapat dilihat pada Tabel 3.

\section{Hasil Eksekusi dari Langkah 9:}

Oleh karena skor total keseluruhan dari Pilihan-i adalah yang tertinggi, maka diputuskan untuk memilih langkah "Koordinasi dengan atasan karyawan yang bersangkutan untuk diberikan pelatihan dasar tentang pengelolaan rantai pasok bagi karyawan baru yang berada di area pekerjaan pengelolaan rantai pasok." sebagai rencana yang akan direkomendasikan kepada pihak manajemen Perseroan Terbatas X untuk dijalankan. Inilah yang menjadi keluaran dari langkah-8.

Keluaran dari Langkah-9 adalah pilihan keputusan yang akan dibuatkan rencana kerjanya.

\section{Simpulan}

Berdasarkan pada studi kasus manajemen rantai pasok di Perseroan Terbatas X, maka dapat disim- pulkan dua hal berikut ini. Pertama, yang menjadi fokus masalah adalah "Rendahnya kompetensi tenaga kerja yang terlibat dalam pengelolaan rantai pasok" dan "Belum berjalannya pengembangan kompetensi karyawan yang terlibat dalam proses rantai pasok", dua fokus masalah terpilih ini menjadi decision area dari penelitian ini. Kedua, dari proses comparing dan choosing, dipilih opsi "koordinasi dengan atasan karyawan yang bersangkutan untuk diberikan pelatihan dasar tentang pengelolaan rantai pasok bagi karyawan baru yang berada di area pekerjaan pengelolaan rantai pasok" sebagai rencana yang akan direkomendasikan kepada pihak manajemen untuk dijalankan.

Langkah-5 hingga Langkah-8 dari usulan metode penstrukturan masalah adalah langkah-langkah pada metode SCA. Langkah-langkah ini dapat secara interaktif dijalankan dengan perangkat lunak "STRAD" (STRategic ADviser), sehingga metode usulan ini dapat dikombinasikan dengan perangkat lunak ini dalam penerapannya.

\section{Daftar Pustaka}

1. Reid, C., Hilbert, Springer Science+Business Media, New York, USA, 1996.

2. Prayitno, Wawasan dan Landasan BK (Buku II). Depdiknas: Jakarta, 2003.

3. Johns, G., and, Saks, A. M., Organizational Behavior:Understanding and Managing Life at Work, Pearson Education Canada, Toronto, 2013.

4. Basarah, I. M., dan Susanto, S., Penerapan Teknik Strategic Choice Approach dalam Penstrukturan Masalah Manajemen rantai pasokan, Prosiding Seminar Nasional Teknik Industri Universitas Kristen Petra, 2014, pp 141-147.

5. Pujawan, I. N, Supply Chain Mangement, Penerbit Guna Widya, Surabaya, 2010.

6. Daellenbach, H., McNickle, D., and Dye, S., Management Science: Decision-making through Systems Thinking, Palgrave Macmillan, 2012.

7. Ates, N. Y., and Cevik, S., Modeling the Supply Chain: A Fuzzy Linear Optimization Approach, Applied Artificial Intelligence, 2006, pp.321-328

8. Gokhan, N. M., Needy, K. L., and Norman, B. A., Development of a Simultaneous Design for Supply Chain Process for the Optimization of the Product Design and Supply Chain Configuration Problem, Engineering Management Journal, 22(4), 2010, pp. 20-30.

9. Serdarasan, S., A Review of Supply Chain Complexity Drivers. Computers \& Industrial Engineering, 66(3), 2013, pp. 533-540.

10. Gupta, A., and Evans, G. W., Optimization Modeling for the Operation of Closed-loop Supply Chains, Electronic Theses and Dissertations. Paper 548, 2007. 
11. Baer, M., Dirks, K. T., and Nickersen, J. A., A Theory of Strategic Problem Formulation. Olin School of Business Working Paper, 2008, pp. 1-47.

12. Cutting-Decelle, Francoise, A., Young, B. I., Das, B.P., Case, K., Rahimifard, S., Anumba, C. J., and Bouchlaghem, D. M., A Review of Approaches to Supply Chain Communications: from Manufacturing to Construction, Itcon, 12, 2007, pp. 73-102

13. Bakker, F., Boehme, T., and van Donk, D. P., Identifying Barriers to Internal Supply Chain Integration using Systems Thinking. $4^{\text {th }}$, Production and Operations Management $W$ orld Conference. Amsterdam: EurOMA, 2012, pp. 1-10

14. Sweeney, E., The Systems Approach to Analysing Supply Chains and Improving Their Performance. Perspectives on Purchasing for the New Millenium, Proceedings of the 8th International Purchasing and Supply Education and Research Association (IPSERA) Conference, Belfast, 1999, pp. 739-744.
15. Sweeney, E., The Systems Approach to Supply Chain Re-Engineering. Marketing News, The Journal of the Marketing Institute of Ireland, 12(13), 2000, pp.14-15

16. Szymcak, M., Szuster, M., Wietska, G., and Baraniecka, A., 2013. "Managing Towards Supply Chain Maturity Business Process Outsourcing and Offshoring".

17. Ghadge, A., Dani, S., Chester, M., and Kalawsky, R., A Systems Approach for Modelling Supply Chain Risks, Supply Chain Management: An International Journal 18(5), 2013, pp. 523-538.

18. Mingers, J., Soft OR Comes of Age-But Not Everywhere!, Omega, 39(6), 2011, pp. 729-741.

19. Friend, J. K., and Hickling, A., Planning Under Pressure: The Strategic Choice Approach $3^{\text {rd }}$, Butterworth-Heinemann, Oxford, 2005.

20. Winston, W. L., Operations Research: Applications and Algorithms, Brooks/Cole, Belmont, CA, 2004. 